\title{
Marinibacillus campisalis sp. nov., a moderate halophile isolated from a marine solar saltern in Korea, with emended description of the genus Marinibacillus
}

\author{
Jung-Hoon Yoon, ${ }^{1}$ In-Gi Kim, ${ }^{2}$ Peter Schumann, ${ }^{3}$ Tae-Kwang Oh ${ }^{1}$ \\ and Yong-Ha Park ${ }^{1,2}$ \\ ${ }^{1}$ Korea Research Institute of Bioscience and Biotechnology (KRIBB), PO Box 115, Yusong,
Taejon, Korea \\ ${ }^{2}$ National Research Laboratory of Molecular Ecosystematics, Institute of Probionic, Probionic \\ Corporation, Bio-venture Center, Korea Research Institute of Bioscience and Biotechnology \\ (KRIBB), PO Box 115, Yusong, Taejon, Korea \\ ${ }^{3} \mathrm{DSMZ}$ - Deutsche Sammlung von Mikroorganismen und Zellkulturen $\mathrm{GmbH}$, Mascheroder \\ Weg 1b, D-38124 Braunschweig, Germany
}

\begin{abstract}
A Gram-positive, motile, round to ellipsoidal, endospore-forming, rod-shaped bacterial strain, SF $-57^{\top}$, was isolated from a marine solar saltern in Korea. This organism grew between 4 and $39^{\circ} \mathrm{C}$, with optimum growth at $30{ }^{\circ} \mathrm{C}$. Strain SF- $57^{\top}$ grew in the presence of $0.5-15 \cdot 0 \% \mathrm{NaCl}$, with optimum growth at $2-3 \% \mathrm{NaCl}$. The peptidoglycan type of strain SF-57 $7^{\top}$ was $\mathrm{A} 1 \alpha$ linked directly through L-Lys. In strain SF- $57^{\top}$, menaquinone-7 (MK-7) was the predominant isoprenoid quinone and anteiso- $C_{15: 0}$ was the major fatty acid. The DNA G+C content was $41.8 \mathrm{~mol} \%$. Phylogenetic analyses based on 16S rRNA gene sequences showed that strain SF- $57^{\top}$ formed a coherent cluster with Marinibacillus marinus, with a bootstrap resampling value of $100 \%$. The level of $16 \mathrm{~S}$ rRNA gene sequence similarity between strain SF- $57^{\top}$ and M. marinus DSM $1297^{\top}$ was $98.9 \%$. The mean DNA-DNA relatedness level between strain SF- $57^{\top}$ and the type strain of M. marinus was $20 \cdot 6 \%$. Based on phenotypic properties, phylogenetic analyses and genomic data, strain SF $-57^{\top}$ merits placement in the genus Marinibacillus as a representative of a novel species, for which the name Marinibacillus campisalis sp. nov. is proposed.

The type strain is SF $-57^{\top}\left(=\operatorname{KCCM~} 41644^{\top}=\mathrm{JCM} 11810^{\top}\right)$.
\end{abstract}

Bacillus species belonging to rRNA group 2 have been differentiated from other Bacillus species by their type of cell wall peptidoglycan and endospore shape, as well as by phylogenetic inference (Ash et al., 1991; Rheims et al., 1999; Stackebrandt et al., 1987). Such observations have suggested that rRNA group 2 Bacillus species may be members of genera other than the genus Bacillus (Farrow et al., 1994; Rheims et al., 1999; Yoon et al., 2001a). Differential taxonomic data have recently permitted reassignment of some rRNA group 2 Bacillus species to other existing genera or to new genera. Bacillus globisporus, Bacillus psychrophilus

Published online ahead of print on 30 January 2004 as DOI 10.1099/ ijs.0.02779-0.

The GenBank/EMBL/DDBJ accession number for the 16S rRNA gene sequence of Marinibacillus campisalis SF- $57^{\top}$ is AY 190535.

A phylogenetic tree is available as supplementary material in IJSEM Online. and Bacillus pasteurii have been transferred to the genus Sporosarcina, and Bacillus marinus has been reclassified as a member of a new genus, Marinibacillus (Yoon et al., 2001a, b). Recently, a round to ellipsoidal, endosporeforming Gram-positive rod (strain SF-57 ${ }^{\mathrm{T}}$ ) was isolated from a marine solar saltern, Baekryung Island, Korea. This organism was phylogenetically related to Bacillus rRNA group 2, particularly to the genera Marinibacillus and Jeotgalibacillus, based on 16S rRNA gene sequence comparisons. Accordingly, the aim of the present study was to determine the exact taxonomic position of strain $\mathrm{SF}-57^{\mathrm{T}}$ using a combination of phenotypic properties, detailed phylogenetic analyses based on 16S rRNA gene sequences and genomic relatedness.

Strain SF- $57^{\mathrm{T}}$ was isolated by the standard dilution plating technique on marine agar 2216 (MA; Difco). Marinibacillus marinus DSM $1297^{\mathrm{T}}$, used as a reference strain, was obtained from the Deutsche Sammlung von Mikroorganismen und 
Zellkulturen (DSMZ), Braunschweig, Germany. Cell mass of strain $\mathrm{SF}-57^{\mathrm{T}}$ for analyses of cell wall and menaquinones was obtained from cultures grown in marine broth 2216 (MB; Difco) at $30^{\circ} \mathrm{C}$. For DNA extraction, strain SF-57 and M. marinus DSM $1297^{\mathrm{T}}$ were cultivated in MB at $30^{\circ} \mathrm{C}$. For fatty acid methyl ester analysis, cell mass of strain SF $-57^{\mathrm{T}}$ was obtained from agar plates after cultivation for 3 days at $30^{\circ} \mathrm{C}$ on MA. Cell morphology was observed with a Nikon light microscope. Flagellum type was examined using TEM with cells from exponentially growing cultures. Gram reaction was determined using the bioMérieux Gram Stain kit according to the manufacturer's instructions. Growth at various $\mathrm{NaCl}$ concentrations was investigated in $\mathrm{MB}$. The $\mathrm{pH}$ range for growth was determined in $\mathrm{MB}$ adjusted to various $\mathrm{pH}$ values ( $\mathrm{pH} 4 \cdot 5-9 \cdot 5$ at intervals of $0.5 \mathrm{pH}$ units). Growth at various temperatures was measured on $\mathrm{MA}$ at $4-50{ }^{\circ} \mathrm{C}$. Growth under anaerobic conditions was determined by incubation in an anaerobic chamber on MA that had been prepared anaerobically. All physiological tests were performed at $30^{\circ} \mathrm{C}$, except for temperature range determinations. Oxidase activity was determined by examining oxidation of $1 \%(\mathrm{w} / \mathrm{v}) p$ aminodimethylaniline oxalate. Catalase activity was determined by bubble production in a $3 \%(\mathrm{v} / \mathrm{v}) \mathrm{H}_{2} \mathrm{O}_{2}$ solution. Hydrolysis of casein, starch and Tween 80, and urease activity were determined as described by Cowan \& Steel (1965). Hydrolysis of aesculin and gelatin, and nitrate reduction were studied as described previously (Lanyi, 1987 ) with a modification that artificial sea water was used instead of distilled water. Artificial sea water contained $\left(1^{-1}\right.$ distilled water) $23.6 \mathrm{~g} \mathrm{NaCl}, 0.64 \mathrm{~g} \mathrm{KCl}, 4.53 \mathrm{~g}$ $\mathrm{MgCl}_{2} \cdot 6 \mathrm{H}_{2} \mathrm{O}, 5.94 \mathrm{~g} \mathrm{MgSO}_{4} .7 \mathrm{H}_{2} \mathrm{O}$ and $1.3 \mathrm{~g} \mathrm{CaCl}_{2} \cdot 2 \mathrm{H}_{2} \mathrm{O}$ (Levring, 1946). Hydrolysis of birchwood xylan (Sigma) was determined on solid marine salts basal medium (Baumann \& Baumann, 1981) containing 0.5\% (w/v) xylan as sole carbon source. $\mathrm{H}_{2} \mathrm{~S}$ production was tested as described previously (Bruns et al., 2001). Hydrolysis of hypoxanthine, tyrosine and xanthine was tested on MA plates using substrate concentrations described previously (Cowan \& Steel, 1965). Acid production from carbohydrates was determined as described by Leifson (1963).

Preparation of cell wall samples and determination of peptidoglycan structure were carried out using the methods described by Schleifer (1985) and Schleifer \& Kandler (1972), except that TLC on cellulose sheets was used instead of paper chromatography. GC-MS analysis of amino acid derivatives was performed as described by MacKenzie (1987). Menaquinones were analysed as described by Komagata \& Suzuki (1987) using reversed-phase HPLC. For quantitative analysis of cellular fatty acid compositions, a loopful of cell mass was harvested and fatty acid methyl esters were prepared by the standard protocol of the MIDI/Hewlett Packard Microbial Identification system (Sasser, 1990). Chromosomal DNA was isolated and purified according to a method described previously (Yoon et al., 1996), except that ribonuclease T1 was used with ribonuclease A. DNA G $+\mathrm{C}$ content was determined by the method of Tamaoka \& Komagata (1984). DNA was hydrolysed and the resultant nucleotides were analysed by reversed-phase HPLC.

The 16S rRNA gene was amplified by PCR using two universal primers as described previously (Yoon et al., 1998). The PCR product was purified with a QIAquick PCR purification kit (Qiagen). Sequencing of the purified 16S rRNA gene was performed using an ABI PRISM BigDye Terminator cycle sequencing ready reaction kit (Applied Biosystems) as recommended by the manufacturer. The purified sequencing reaction mixtures were electrophoresed automatically on an Applied Biosystems model 377 automatic DNA sequencer. Alignment of sequences was carried out with CLUSTAL W software (Thompson et al., 1994). Gaps at the $5^{\prime}$ and $3^{\prime}$ ends of the alignment were omitted from further analyses. Phylogenetic analyses were performed as described by Yoon et al. (2001b). DNA-DNA hybridization was performed fluorometrically by the method of Ezaki et al. (1989) using photobiotin-labelled DNA probes and microdilution wells. Hybridization reactions were replicated five times for each sample. Of the values obtained, the highest and lowest values in each sample were excluded and the remaining three measurements were used to calculate the mean relatedness value.

Strain SF- $57^{\mathrm{T}}$ was motile by means of a single polar flagellum. This flagellation pattern differed from the peritrichous pattern exhibited by members of the genus Jeotgalibacillus and M. marinus (Rüger, 1983; Yoon et al., 2001b). Phenotypic properties of strain SF- $57^{\mathrm{T}}$ are shown in Table 1 or are given in the species description (see below). As shown in Table 1, some differences are observed between strain $\mathrm{SF}-57^{\mathrm{T}}$ and M. marinus.

Strain $\mathrm{SF}-57^{\mathrm{T}}$ did not contain any diaminopimelic acid as the diagnostic diamino acid in the cell wall peptidoglycan. The cell wall of strain SF- $57^{\mathrm{T}}$ contained peptidoglycan directly cross-linked with L-lysine as the diagnostic diamino acid. Accordingly, the peptidoglycan type of SF- $57^{\mathrm{T}}$ was concluded to be A1 $\alpha$, based directly on L-Lys, as described by Schleifer \& Kandler (1972). Dinitrophenylated cell walls of strain SF- $57^{\mathrm{T}}$ contained only DNP-lysine. This peptidoglycan type has also been found in the genera Marinibacillus and Jeotgalibacillus among members of the Bacillus rRNA group 2 (Rüger et al., 2000; Yoon et al., 2001b) The predominant menaquinone found in strain SF- $57^{\mathrm{T}}$ was menaquinone-7 (MK-7) (approx. 76\%) and minor amounts of MK-8 (approx. $20 \%$ ) were detected. Whereas the level of MK-7 in the type strain of M. marinus was $87 \%$, the amount of this menaquinone in the genus Jeotgalibacillus was $62 \%$ (Yoon et al., 2001b). Strain SF-57 has a cellular fatty acid profile containing large amounts of branched and unsaturated fatty acids; the major fatty acid was anteiso- $\mathrm{C}_{15: 0}$. This cellular fatty acid profile of strain $\mathrm{SF}-57^{\mathrm{T}}$ was more similar to that of the genus Marinibacillus than to that of the genus Jeotgalibacillus (Table 2). The cellular fatty acid profile of the genus Marinibacillus is characterized by the predominance of 


\section{Table 1. Phenotypic characteristics of strain SF- $57^{\top}$ and $M$. marinus}

+ , Positive reaction; -, negative reaction; $\mathrm{w}+$, weakly positive reaction; $\mathrm{v}$, variable reaction. Both species were rods and positive for growth at $5{ }^{\circ} \mathrm{C}$, motility and catalase. Both species were negative for anaerobic growth, growth without $\mathrm{NaCl}$, decomposition of urea, and acid production from L-arabinose, lactose, D-raffinose, L-rhamnose and D-sorbitol. Data in parentheses are for the type strain of M. marinus.

\begin{tabular}{|c|c|c|}
\hline Characteristic & Strain SF- $57^{\mathrm{T}}$ & Marinibacillus marinus ${ }^{\star}$ \\
\hline Spore shape & Round or ellipsoidal & Round or slightly ellipsoidal \\
\hline Spore position & Terminal or subterminal & Terminal or subterminal \\
\hline Swollen sporangia & Slight & - or slight \\
\hline Gram staining & + or $\mathrm{V}$ & + \\
\hline Flagellum type & Single polar & Peritrichous \\
\hline Cytochrome oxidase & - & $\mathrm{V}(-)$ \\
\hline Nitrate reduction & + & $\mathrm{V}(-)$ \\
\hline $\mathrm{H}_{2} \mathrm{~S}$ production & - & $\mathrm{v}(+)$ \\
\hline \multicolumn{3}{|l|}{ Decomposition of: } \\
\hline Aesculin & + & $\mathrm{V}(+)$ \\
\hline Casein & + & $\mathrm{v}(+)$ \\
\hline Gelatin & - & $\mathrm{v}(+)$ \\
\hline Hypoxanthine & - & $(-)$ \\
\hline Starch & + & - \\
\hline Tween 80 & - & $(-)$ \\
\hline Tyrosine & - & $(-)$ \\
\hline Xanthine & - & $(-)$ \\
\hline \multicolumn{3}{|l|}{ Acid production from: $\dagger$} \\
\hline D-Glucose & + & $\mathrm{v}(+)$ \\
\hline Maltose & + & $\mathrm{v}(+)$ \\
\hline D-Trehalose & + & $\mathrm{v}(+)$ \\
\hline D-Cellobiose & + & - \\
\hline D-Xylose & - & $\mathrm{v}(+)$ \\
\hline D-Mannitol & + & - \\
\hline D-Mannose & - & $\mathrm{v}(+)$ \\
\hline Sucrose & + & - \\
\hline \multicolumn{3}{|l|}{ Growth at: } \\
\hline $7 \% \mathrm{NaCl}$ & + & $\mathrm{V}(\mathrm{w}+)$ \\
\hline $10 \% \mathrm{NaCl}$ & + & - \\
\hline \multicolumn{3}{|l|}{ Growth at: } \\
\hline $30^{\circ} \mathrm{C}$ & + & $\mathrm{v}(+)$ \\
\hline $37^{\circ} \mathrm{C}$ & + & - \\
\hline Optimum growth temperature $\left({ }^{\circ} \mathrm{C}\right)$ & 30 & $12-23$ \\
\hline Maximum growth temperature $\left({ }^{\circ} \mathrm{C}\right)$ & 39 & 30 \\
\hline DNA G $+\mathrm{C}$ content $(\mathrm{mol} \%)$ & $41 \cdot 8$ & $36 \cdot 9-41 \cdot 6$ \\
\hline
\end{tabular}

${ }^{\star}$ Data from Rüger \& Richter (1979), Rüger (1983), Rüger et al. (2000) and Yoon et al. (2001b).

$\dagger$ Isomer type of sugar (D or L) for M. marinus is unknown.

anteiso- $\mathrm{C}_{15: 0}$, whereas the genus Jeotgalibacillus is characterized by the predominance of iso- $\mathrm{C}_{15: 0}$ (Table 2 ). Noteworthy differences were also found between strain SF- $57^{\mathrm{T}}$ and the type strain of $M$. marinus in the proportions of some fatty acids, particularly iso- $\mathrm{C}_{14: 0}$, iso- $\mathrm{C}_{15: 0}$ and $\mathrm{C}_{16: 1} \omega 7 c$ alcohol (Table 2). The DNA G $+\mathrm{C}$ content of strain $\mathrm{SF}-57^{\mathrm{T}}$ was $41 \cdot 8 \mathrm{~mol} \%$.

An almost-complete $16 \mathrm{~S}$ rRNA gene sequence of strain SF- $57^{\mathrm{T}}$ comprising 1506 nt (approx. $96 \%$ of the Escherichia coli $16 \mathrm{~S}$ rRNA gene sequence) was determined directly after PCR amplification. Phylogenetic trees based on 16S rRNA gene sequences showed that strain $\mathrm{SF}-57^{\mathrm{T}}$ was closely related to the genera Marinibacillus and Jeotgalibacillus. In the tree generated using the neighbour-joining algorithm, strain SF $-57^{\mathrm{T}}$ and $M$. marinus formed a coherent cluster supported by bootstrap analysis at a confidence level of $100 \%$ (the phylogenetic tree is available as supplementary material in IJSEM Online). This cluster joined to the evolutionary lineage of Jeotgalibacillus alimentarius; this 
Table 2. Cellular fatty acid profiles (\%) of strain SF- $57^{\top}$, M. marinus DSM $1297^{\top}$ and J. alimentarius KCCM $80002^{\top}$

\begin{tabular}{|c|c|c|c|}
\hline Fatty acid & $\begin{array}{l}\text { Strain } \\
\text { SF-57 }\end{array}$ & $\begin{array}{l}\text { M. marinus } \\
\text { DSM } 1297^{\mathrm{T}}\end{array}$ & 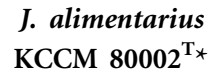 \\
\hline \multicolumn{4}{|c|}{ Straight-chain fatty acids: } \\
\hline $\mathrm{C}_{14: 0}$ & $0 \cdot 8$ & ND & $0 \cdot 7$ \\
\hline $\mathrm{C}_{15: 0}$ & $1 \cdot 1$ & $\mathrm{ND}$ & $1 \cdot 1$ \\
\hline $\mathrm{C}_{16: 0}$ & $0 \cdot 9$ & $1 \cdot 5$ & $3 \cdot 9$ \\
\hline $\mathrm{C}_{18: 0}$ & ND & ND & $3 \cdot 4$ \\
\hline \multicolumn{4}{|l|}{ Branched fatty acids: } \\
\hline iso- $\mathrm{C}_{14: 0}$ & $14 \cdot 1$ & $5 \cdot 3$ & $2 \cdot 1$ \\
\hline iso- $\mathrm{C}_{15: 0}$ & $2 \cdot 5$ & $22 \cdot 2$ & $47 \cdot 6$ \\
\hline anteiso- $\mathrm{C}_{15: 0}$ & $49 \cdot 8$ & $47 \cdot 7$ & $15 \cdot 2$ \\
\hline iso- $\mathrm{C}_{16: 0}$ & $5 \cdot 2$ & $5 \cdot 1$ & $1 \cdot 9$ \\
\hline iso- $\mathrm{C}_{17: 0}$ & ND & $2 \cdot 6$ & $6 \cdot 5$ \\
\hline anteiso- $\mathrm{C}_{17: 0}$ & $7 \cdot 4$ & $10 \cdot 7$ & $4 \cdot 6$ \\
\hline iso- $\mathrm{C}_{17: 1} \omega 10 c$ & & & $3 \cdot 8$ \\
\hline \multicolumn{4}{|c|}{ Unsaturated fatty acids: } \\
\hline $\mathrm{C}_{16: 1} \omega 7 c$ alcohol & $12 \cdot 3$ & $2 \cdot 6$ & $5 \cdot 2$ \\
\hline $\mathrm{C}_{16: 1} \omega 11 c$ & $1 \cdot 9$ & $\mathrm{ND}$ & $1 \cdot 2$ \\
\hline Summed feature $4 \dagger$ & $3 \cdot 9$ & $2 \cdot 3$ & $2 \cdot 3$ \\
\hline
\end{tabular}

ND, Not detected.

${ }^{*}$ Data from Yoon et al. (2001b).

†Summed feature 4 contained one or more of following fatty acids: iso- $\mathrm{C}_{17: 1} \mathrm{I}$ and/or ante- $\mathrm{C}_{17: 1} \mathrm{~B}$, which could not be separated by GLC with the MIDI system.

relationship was supported by a bootstrap resampling value of $98.6 \%$. A similar phylogenetic relationship between strain SF-57 ${ }^{\mathrm{T}}$, M. marinus, J. alimentarius and other members of Bacillus rRNA group 2 was also observed in trees generated with maximum-likelihood and maximumparsimony algorithms (data not shown). The level of $16 \mathrm{~S}$ rRNA gene sequence similarity between strain SF- $57^{\mathrm{T}}$ and M. marinus DSM $1297^{\mathrm{T}}$ was $98 \cdot 9 \%$. Strain SF- $57^{\mathrm{T}}$ exhibited 95.9\% $16 \mathrm{~S}$ rRNA gene sequence similarity to J. alimentarius KCCM $80002^{\mathrm{T}}$ and less than $94 \cdot 1 \%$ similarity to other species used in the phylogenetic analyses. The mean level of DNA-DNA relatedness between strain SF- $57^{\mathrm{T}}$ and $M$. marinus DSM $1297^{\mathrm{T}}$ was $20 \cdot 6 \%$, when each of their DNAs was separately used as labelled DNA probe. These data indicate that strain $\mathrm{SF}-57^{\mathrm{T}}$ is a member of a genomic species that is distinct from M. marinus (Wayne et al., 1987).

Strain SF- $57^{\mathrm{T}}$ exhibited closest phylogenetic affiliation to M. marinus according to $16 \mathrm{~S}$ rRNA gene sequence analyses (phylogenetic tree available in IJSEM Online). The chemotaxonomic traits of strain $\mathrm{SF}-57^{\mathrm{T}}$ are most similar to those of the genus Marinibacillus (Yoon et al., 2001b). Therefore, both phylogenetic and chemotaxonomic results clearly indicate that strain $\mathrm{SF}-57^{\mathrm{T}}$ belongs to the genus Marinibacillus. The levels of DNA-DNA relatedness, together with some differing phenotypic properties and phylogenetic distinctiveness, justify separation of strain $\mathrm{SF}-57^{\mathrm{T}}$ from
M. marinus, the single species of the genus Marinibacillus (Wayne et al., 1987). Therefore, on the basis of phenotypic, chemotaxonomic and phylogenetic data, and genomic distinctiveness, strain $\mathrm{SF}-57^{\mathrm{T}}$ should be classified as a representative of a novel species in the genus Marinibacillus; the name Marinibacillus campisalis sp. nov. is proposed.

\section{Description of Marinibacillus campisalis sp. nov.}

Marinibacillus campisalis (cam.pi.sa'lis. L. n. campus field; L. gen. n. salis of salt; N.L. gen. n. campisalis of the field of salt).

Cells are rods, $1 \cdot 3-1 \cdot 6 \times 2 \cdot 5-4 \cdot 0 \mu \mathrm{m}$. Gram-positive, but Gram-variable in older cultures. Round to ellipsoidal endospores lie centrally or subterminally in slightly swollen sporangia. Colonies are smooth, glistening, circular to slightly irregular, flat to raised, light orange-yellow in colour and $2-3 \mathrm{~mm}$ in diameter after 3 days incubation on marine agar 2216. Growth occurs at $4{ }^{\circ} \mathrm{C}$; maximum growth temperature is $39^{\circ} \mathrm{C}$. Optimal $\mathrm{pH}$ for growth is $7 \cdot 0-8 \cdot 0$; no growth occurs at $\mathrm{pH} 4 \cdot 5$. Optimal growth occurs in the presence of 2-3\% (w/v) NaCl. Growth occurs in the presence of $15 \% \mathrm{NaCl}$, but not $16 \% \mathrm{NaCl}$. Xylan is not hydrolysed. Acid is produced from D-fructose and melibiose, and weakly produced from D-melezitose. Acid is not produced from adonitol, D-galactose, myo-inositol, D-ribose or stachyose. Other characteristics are given in Table 1 . The peptidoglycan type is A $1 \alpha$ (L-Lys direct). The predominant menaquinone is MK-7. The major fatty acid is anteiso- $\mathrm{C}_{15: 0}$.

The type strain, SF- $57^{\mathrm{T}}\left(=\mathrm{KCCM} 41644^{\mathrm{T}}=\mathrm{JCM} 11810^{\mathrm{T}}\right)$, was isolated from a marine solar saltern in Korea. Its DNA $\mathrm{G}+\mathrm{C}$ content is $41 \cdot 8 \mathrm{~mol} \%$ (determined by HPLC).

\section{Emended description of the genus Marinibacillus}

The description of the genus Marinibacillus is as given by Yoon et al. (2001b) but with the following amendments. Motile by means of single polar flagellum or peritrichous flagella. Starch hydrolysis is variable. Growth at $37^{\circ} \mathrm{C}$ is variable. Growth in the presence of $10 \% \mathrm{NaCl}$ is variable. The DNA G + C content is $36 \cdot 9-41 \cdot 8 \mathrm{~mol} \%$.

\section{Acknowledgements}

This work was supported by the $21 \mathrm{C}$ Frontier programme of Microbial Genomics and Applications (grant MG02-0401-001-1-0-0) and the NRL research programme (grant M10104000294-01J000012811) from the Ministry of Science and Technology (MOST) of the Republic of Korea and by the research fund of Probionic Corporation of Korea.

\section{References}

Ash, C., Farrow, J. A. E., Wallbanks, S. \& Collins, M. D. (1991). Phylogenetic heterogeneity of the genus Bacillus as revealed by comparative analysis of small-subunit-ribosomal RNA sequences. Lett Appl Microbiol 13, 202-206. 
Baumann, L. \& Baumann, P. (1981). The marine Gram-negative eubacteria; genera Photobacterium, Beneckea, Alteromonas, Pseudomonas, and Alcaligenes. In The Prokaryotes, pp. 1302-1330. Edited by M. P. Starr, H. Stolp, H. G. Trüper, A. Balows \& H. G. Schlegel. Berlin: Springer.

Bruns, A., Rohde, M. \& Berthe-Corti, L. (2001). Muricauda ruestringensis gen. nov., sp. nov., a facultatively anaerobic, appendaged bacterium from German North Sea intertidal sediment. Int J Syst Evol Microbiol 51, 1997-2006.

Cowan, S. T. \& Steel, K. J. (1965). Manual for the Identification of Medical Bacteria. London: Cambridge University Press.

Ezaki, T., Hashimoto, Y. \& Yabuuchi, E. (1989). Fluorometric deoxyribonucleic acid-deoxyribonucleic acid hybridization in microdilution wells as an alternative to membrane filter hybridization in which radioisotopes are used to determine genetic relatedness among bacterial strains. Int J Syst Bacteriol 39, 224-229.

Farrow, J. A. E., Wallbanks, S. \& Collins, M. D. (1994). Phylogenetic interrelationships of round-spore-forming bacilli containing cell walls based on lysine and the non-spore-forming genera Caryophanon, Exiguobacterium, Kurthia, and Planococcus. Int J Syst Bacteriol 44, 74-82.

Komagata, K. \& Suzuki, K. I. (1987). Lipid and cell-wall analysis in bacterial systematics. Methods Microbiol 19, 161-206.

Lanyi, B. (1987). Classical and rapid identification methods for medically important bacteria. Methods Microbiol 19, 1-67.

Leifson, E. (1963). Determination of carbohydrate metabolism of marine bacteria. J Bacteriol 85, 1183-1184.

Levring, T. (1946). Some culture experiments with Ulva and artificial seawater. K Fysiogr Sallsk Lund Forh 16, 45-56.

MacKenzie, S. L. (1987). Gas chromatographic analysis of amino acids as the $N$-heptafluorobutyryl isobutyl esters. J Assoc Off Anal Chem 70, 151-160.

Rheims, H., Frühling, A., Schumann, P., Rohde, M. \& Stackebrandt, E. (1999). Bacillus silvestris sp. nov., a new member of the genus Bacillus that contains lysine in its cell wall. Int J Syst Bacteriol 49, 795-802.

Rüger, H.-J. (1983). Differentiation of Bacillus globisporus, Bacillus marinus comb. nov., Bacillus aminovorans, and Bacillus insolitus. Int J Syst Bacteriol 33, 157-161.

Rüger, H. J. \& Richter, G. (1979). Bacillus globisporus subsp. marinus subsp. nov. Int J Syst Bacteriol 29, 196-203.

Rüger, H. J., Fritze, D. \& Spröer, C. (2000). New psychrophilic and psychrotolerant Bacillus marinus strains from tropical and polar deep-sea sediments and emended description of the species. Int J Syst Evol Microbiol 50, 1305-1313.
Sasser, M. (1990). Identification of bacteria by gas chromatography of cellular fatty acids. Technical Note 101. Newark, DE: MIDI.

Schleifer, K. H. (1985). Analysis of the chemical composition and primary structure of murein. Methods Microbiol 18, 123-156.

Schleifer, K. H. \& Kandler, O. (1972). Peptidoglycan types of bacterial cell walls and their taxonomic implications. Bacteriol Rev 36, 407-477.

Stackebrandt, E., Ludwig, W., Weizenegger, M., Dorn, S., McGill, T. J., Fox, G. E., Woese, C. E., Schubert, W. \& Schleifer, K.-H. (1987). Comparative $16 \mathrm{~S}$ rRNA oligonucleotide analyses and murein types of round-spore-forming bacilli and non-spore-forming relatives. J Gen Microbiol 133, 2523-2529.

Tamaoka, J. \& Komagata, K. (1984). Determination of DNA base composition by reversed-phase high-performance liquid chromatography. FEMS Microbiol Lett 25, 125-128.

Thompson, J. D., Higgins, D. G. \& Gibson, T. J. (1994). CLUSTAL W: improving the sensitivity of progressive multiple sequence alignment through sequence weighting, position-specific gap penalties and weight matrix choice. Nucleic Acids Res 22, 4673-4680.

Wayne, L. G., Brenner, D. J., Colwell, R. R. \& 9 other authors (1987). International Committee on Systematic Bacteriology. Report of the ad hoc committee on reconciliation of approaches to bacterial systematics. Int J Syst Bacteriol 37, 463-464.

Yoon, J.-H., Kim, H., Kim, S.-B., Kim, H.-J., Kim, W. Y., Lee, S. T., Goodfellow, M. \& Park, Y.-H. (1996). Identification of Saccharomonospora strains by the use of genomic DNA fragments and rRNA gene probes. Int J Syst Bacteriol 46, 502-505.

Yoon, J.-H., Lee, S. T. \& Park, Y.-H. (1998). Inter- and intraspecific phylogenetic analysis of the genus Nocardioides and related taxa based on $16 \mathrm{~S}$ rDNA sequences. Int J Syst Bacteriol 48, 187-194.

Yoon, J.-H., Lee, K.-C., Weiss, N., Kho, Y. H., Kang, K. H. \& Park, Y.-H. (2001a). Sporosarcina aquimarina sp. nov., a bacterium isolated from seawater in Korea, and transfer of Bacillus globisporus (Larkin and Stokes 1967), Bacillus psychrophilus (Nakamura 1984) and Bacillus pasteurii (Chester 1898) to the genus Sporosarcina as Sporosarcina globispora comb. nov., Sporosarcina psychrophila comb. nov. and Sporosarcina pasteurii comb. nov., and emended description of the genus Sporosarcina. Int J Syst Evol Microbiol 51, 1079-1086.

Yoon, J.-H., Weiss, N., Lee, K.-C., Lee, I.-S., Kang, K. H. \& Park, Y.-H. (2001b). Jeotgalibacillus alimentarius gen. nov., sp. nov., a novel bacterium isolated from jeotgal with L-lysine in the cell wall, and reclassification of Bacillus marinus Rüger 1983 as Marinibacillus marinus gen. nov., comb. nov. Int J Syst Evol Microbiol 51, 2087-2093. 